\title{
Clarification of orange juice by crude fungal pectinase from citrus peel
}

\author{
Kareem S.O ${ }^{1}$ and *Adebowale, A.A. ${ }^{2 *}$ \\ ${ }^{1}$ Department of Microbiology, University of Agriculture, Abeokuta, Nigeria. \\ ${ }^{2}$ Department of Food Science and Technology, University of Agriculture, Abeokuta, Nigeria. \\ *Address for Correspondence:E-mail: deboraz2002@ yahoo.com
}

\begin{abstract}
Fungal pectinase enzyme was produced by Rhizopus oryzae on a solid culture containing citrus peel of orange (35\% $\mathrm{w} / \mathrm{v})$. The crude extract with maximum pectinase activity of $1,360 \mathrm{u} / \mathrm{ml}$ was used to clarify orange juice. The yield, turbidity and viscosity as well as $\mathrm{pH}$, total soluble solids, ascorbic acids and total titratable acidity of the clarified juice were determined. The optimum yield (97\%) of juice was obtained at $1 \%$ pectinase enzyme concentration, while the turbidity and viscosity decreases with increasing concentration of pectinase enzyme. There were no marked changes in the $\mathrm{pH}$ and total titratable acidity of the pectinase

enzyme treated juice. Ascorbic acid and total soluble solids increase with increasing pectinase enzyme concentration. There were significant differences $(p<0.05)$ in the pectinase enzyme concentrations on the yield, viscosity, turbidity and total titratable acid of the orange juice while no significant $(\mathrm{P}>0.05)$ difference was found in the $\mathrm{pH}$, ascorbic acid and total soluble solids. The results presented citrus peel as substrate for pectinase production and its subsequent use in the clarification of orange juice could enhance fruit juice processing in the tropics.
\end{abstract}

Key words: Orange juice, pectinase, clarification

\section{INTRODUCTION}

$\mathrm{O}^{\prime}$ range (Citrus sinensis) belongs to Citrus fruits and believed to have originated from Asia (Beaven et al, 1972). Citrus fruits and juices serve as primary sources of our daily requirement of Vitamin C. In addition, supplementary nutritional value is obtained from the amino acids, inorganic salt, carbohydrates and probably other still unidentified factors found in the edible pigment (Beaven et al, 1972). Tropical fruit juices have become important in recent years due to the overall increase in "natural fruit" juice consumption as an alternative to the traditional caffeine-containing beverages such as coffee, tea, or carbonated soft drinks. By incorporating tropical fruits into fruit juice blends, food technologists have been able to exploit their exotic flavours without adding artificial flavour.
The demand for and acceptance of citrus fruit in the daily diet of human is based largely on their nutritional value, flavour, aroma and other aesthetic characteristics such as colour, texture and cloudiness (Braddock, 1981). A significant number of consumers do not relish orange juice in hazy or cloudy condition. Therefore, different methods have been used to clarify orange juice such as centrifugation, sedimentation and filtration, none of which has actually met brilliant and polish colour desired by most consumers (Baker and Bruemer, 1972; Braddock, 1981). Consequently, attention is being shifted to the use of pectic enzymes for better clarification.

Pectinases are a group of enzyme that degrade pectin-containing substances into smaller fractions thus resulting into viscosity reduction, less gel formation and high degree of 
juice concentration (Screenath et al, 1987). Several attempts have been made on the production of pectinase by fungi using citrus peels, sugar cane molasses and other agricultural wastes as substrates (Hart et al, 1991, Kareem and Akpan, 2004). However, reports on the use of enzymes in tropical fruit juice processing are limited. This study is an attempt to merge the utilization of citrus peels for pectinase production by Rhizopus oryzae strain and the subsequent utilization of the enzyme for clarifying orange juice.

\section{MATERIALS AND METHODS Microorganism}

Strains of Rhizopus oryzae obtained from the environment were screened for pectinolytic activity using the method of Onyeocha and Ogbona (1983). They were grown on a culture medium containing yeast extract $1 \mathrm{~g} / \mathrm{l}$, agar $15 \mathrm{~g} /$ 1 , and pectin $5 \mathrm{~g} / 1(\mathrm{pH} \mathrm{5})$. The plates were incubated at $30^{\circ} \mathrm{C}$ for $24 \mathrm{hrs}$ and then flooded with $1 \%$ aqueous solution of hexadecyl trimethyl ammonium bromade. The clear zones shown around the fungal clones against the opaque background indicated pectolytic enzyme activity and their sizes were measured accordingly. The pectinase positive strains were stored on potato dextrose agar slants at $4{ }^{\circ} \mathrm{C}$ and sub-cultured twice a month.

\section{Pectinase Production}

The solid culture containing $35 \mathrm{~g}$ dry citrus peel, $0.8 \mathrm{~g}$ urea, and $3.2 \mathrm{~g}$ ammonium sulphate. The mixture was moistened with $20 \mathrm{ml}$ distilled water and autoclaved at $121^{\circ} \mathrm{C}$ for $20 \mathrm{~min}$. After cooling to ambient temperature, it was innoculated with spore suspension (1ml) of $R$. oryzae and incubated at $30^{\circ} \mathrm{C}$ for $72 \mathrm{~h}$. The fermented material was mixed with phosphate buffer $\left(\mathrm{pH} \mathrm{5.0)}\right.$ at ratio $1: 4 \mathrm{w} / \mathrm{v}$ and kept at $4^{\circ} \mathrm{C}$ overnight. The crude extract was partially clarified using Imarsil 1\% (w/v) as described by
Kareem and Akpan (2003). The supernatant was used for the treatment of orange juice.

\section{Enzyme Assay}

The pectinase activity was determined by measuring the reducing sugar produced by 3,5 dinitrosalicylic acid method (Muller, 1959) using galacturonic acid as standard. One exo-pectinase unit is defined as the amount of enzyme that liberated one micromolecule of galacturonic acid equivalent per minute

\section{Extraction of Orange Juice}

Mature ripened orange fruits (Citrus sinensis) were obtained from a major market in Abeokuta, Nigeria. The oranges were sorted, washed and peeled. The juice was extracted using a domestic juice extractor.

\section{Enzyme Treatment of Extracted Juice}

The extracted juice was pasteurized at $85^{\circ} \mathrm{C}$ for $3 \mathrm{~min}$ to inactivate the natural fruit enzymes or microbes present and then cooled down to $40^{\circ} \mathrm{C}$ before the addition of pectinase enzyme. Varying concentration of enzyme $(0,0.25,0.5$ 0.75 and $1 \%$ ) was added. The samples were incubated at $40^{\circ} \mathrm{C}$ for $1 \mathrm{~h}$. After incubation, the samples were treated at $85^{\circ} \mathrm{C}$ for $3 \mathrm{~min}$ to inactivate the enzyme.

\section{METHODS \\ Yield}

The clarified juice was filtered using Whatman No 4 filter paper. The volume of fruit juice obtained from each sample was measured using $200 \mathrm{ml}$ volumetric flask and the weight of juice recorded.

\section{Determination of Turbidity and Viscosity}

Turbidity of clarified juice was measured using a Turbidimeter model 2010 (HACH). The viscosity measurement was made using a Brookfield Viscometer (Model LV) with $600 \mathrm{ml}$ beaker and viscosity reading was taken using spindle No 2 rotated at 30rpm. 
Distilled water) with $0.1 \mathrm{~N} \mathrm{NaOH}$. The acidity value was expressed as citric acid. The $\mathrm{pH}$ value was determined using $\mathrm{pH}$ meter (Jenway Ltd)

Determination of Ascorbic Acid and Total Soluble Sugar

Ascorbic acid content of the clarified juice was determined by 2,6, dichlorophenol indophenol dye titration method (Rangana, 1977). The total solid content was determined using the Abbey Refractometer. Total sugar was determined colorimetrically using the method of Dubois et al, (1986).

\section{Statistical Analysis}

Datas were analyzed using Analysis of Variance (ANOVA) and means separated using Duncan's Multiple Range Test, using SPSS statistical package (SPSS 2002,version 10.0).

\section{RESULTS AND DISCUSSION}

Five strains of Rhizopus oryzae were screened for pectinase production. The results presented in table 1 showed that Rhizopus oligosporus ( $\mathrm{Rx}-02)$ gave the widest zones of hydrolysis ( $8 \mathrm{~mm})$ on pectin-agar medium against the opaque background which is an indication of the ability to degrade pectin into galacturonic acid. The Rhizopus oligosporus ( $\mathrm{Rx}-02)$ gave the highest pectinase activity when cultured on citrus peel and was successfully used to clarify orange juice. The result of the effect of different enzyme concentration on the yield of orange juice is shown in table 2. The yield varied from 73-97\% with untreated juice having the lowest and juice treated with $1 \%$ enzyme concentration had the highest yield. The observation may be due to degradation of pectic substances which lead to increase in the yield of juice (Gerthartz, 1990). There is significant difference $(P<0.05)$ in the yield of orange juice clarified with different concentration of pectinase enzyme (Table 2).
Fig 1 showed that untreated juice was highly turbid (184 NTU), indicating the presence of suspended colloidal particles, which was offset upon enzyme treatment. The turbidity decreased with increase in levels of enzymes used with $2 \%$ enzyme concentration giving the least turbidity of 36 NTU. There is significant difference $(p<0.05)$ in the turbidity of enzyme treated orange juice (Table 2). The result of viscosity showed about $51 \%$ reduction in viscosity in the treated juice compared to untreated juice (Table 2 ). Loss in viscosity has been reported to facilitate the filtration process and increase the efficiency of the juice concentration process (Screenath et al, 1987; Kareem, 1998). There is significant difference $(P<0.05)$ in the viscosity of orange juice clarified with different concentration of pectinase enzyme (Table 2).

The $\mathrm{pH}$ values of enzyme clarified orange is shown in Table 3. The $\mathrm{pH}$ decreases from 3.8 in untreated juice to 3.54 in juice treated with $2.0 \%$ enzyme concentration. The $\mathrm{pH}$ of the juice decreases with increasing levels of enzyme concentration (Fig 2). A further increase in enzyme concentration above $1 \%$ did not significantly decrease the $\mathrm{pH}$ value. According to Baker and Bruemmer (1972), a decrease in $\mathrm{pH}$ value from 4.5 to 3.0 would increase the shelf life about 3 times. In this experiment, the slight decrease in $\mathrm{pH}$ is expected to give an improved quality in treated juice. The total titratable acidity increases from $0.038 \mathrm{~g} / 100 \mathrm{~g}$ in untreated juice to $0.047 \mathrm{~g} / 100 \mathrm{~g}$ in juice treated with $0.5 \%$ enzyme. However, above $0.5 \%$ enzyme concentration the total titratable acidity decreases (Fig 2). The dominant acid in orange juice is citric acid, which increases 4 times after the fruit was harvested (Paull and Chen, 1983). It is an important factor in determining the quality of fruit juice. 
The result of Brix analysis on enzyme treated orange juice indicated a slight increase in soluble solids content from 6.0 to $6.2^{0}$ Brix (Table 2). Arthey and Ashurst (1996) had earlier reported that the Brix content of orange should be within the range of $4^{0}-9^{0}$ Brix. Generally, the variations in enzyme concentration used did not significantly ( $p>0.05)$ affect the Brix value.

The ascorbic acid content of orange juice is normally $53.2 \mathrm{mg} / 100 \mathrm{~g}$ (Siong et al, 1988), but in this experiment it varied from $48.30 \mathrm{mg} / 100 \mathrm{~g}$ as the enzyme level is increased. This may be due to partial loss of nutrient during pasteurization. A similar report by Yusof and Ibrahim, (1994) indicated that the enzyme treatment did not seem to increase the ascorbic acid content.

\section{CONCLUSION}

The pectinase produced by $R$. oryzae degrades polysaccharide materials in the orange juice into smaller fractions thus facilitating filtration; reduction in viscosity and turbidity. It may be deduced that the use of citrus peel as substrate for pectinase production would promote local production of food enzymes. The subsequent application of the fungal pectinase in the clarification of orange juice would enhance the production of clarified fruit juice in the tropics.

\section{REFERENCES}

Arthey, D and Ashurst, P.R. (1996) Production and packaging of non-carbonated fruit juice and fruit beverages. Blackie Academic and Professional, p 152 - 167.

Baker, R.A. and Bruemmer, J.H. (1972) Pectinase stabilization of Orange juice cloud. J. Agric Food Chem. 20 (6) 1169 - 1172.

Beaven, E.A.; Rice, R.G.; Bisset O.W. and Keller, G.T. (1962) Chemical technology of
Citrus product. J. Agric. Food Chem. 2 : 196 198.

Braddock, R.J. (1981) Pectinase Treatment of raw Orange juice and subsequent quality changes in $60^{\circ}$ Brix Concentrate Proc. Florida State Hort. Soc. 94: $270-3$.

Dubois, M; Erilla, K.A.; Hamilton, J.K.; Reber, D.A. and Smiith, F. (1986) Colorimetric Methods for Detection of Sugar and Related Substances. Anal. Chem. 28: 350 - 356.

Gerhartz, W. (1990) Enzyme in Industry. Food Sc. and Tech. 64: $1210-1211$.

Hart, H.E; Parish, M. E.; Burns, J.K. and Wicker, I. (1991) Orange finisher pulp as substrate for polygalacturonase Production by Rhizopus oryzae. Journal of Food Science 56: $480-483$.

Kareem S.O. and Akpan, I. (2003) Clarification of Amylase Extract from Moldy Bran with Imarsil. Enzyme and Microbial Technology 33: $259-261$.

Kareem S.O. and Akpan, I. (2004) Pectinase production on solid state cultures of Rhizopus spp. In Proceedings of the $1^{\text {st }}$ International Conference on Science and National Development. University of Agriculture, Abeokuta. p 94-96.

Muller, L. (1959). Use of dinitrosalicylic acid reagent for determination of reducing sugars. Anal. Chem. 31: 426-428.

Onyeocha, I.O and Ogbonna, C.I.C. (1983) Extracellular enzyme production: a quick qualitative assay method. Nigerian J. Biotech. 1: 48-59.

Paul, R.E and Chen, N. J (1983) Changes in Organic Acid Sugar and head space volatiles 
during fruit ripening of sour sop. J. Am. Soc. Hort. Sci. . 108 (6), 931 - 934.

Rangana, S. (1977) Manual of Analysis of fruits and Vegetable Products, Tata McGraw - Hill Pub. Co. Ltd., New Delhi.

Screenath, H.K.; Nanjundaswamy, A.M. and Sreekantiah, K.R. (1987) Effect of various cellulases and pectinases on viscosity reduction of mango pulp. J. Food Sc. 50 (1) $230-231$.
Siong, T.E,; Noor, M.L.; Azudin, M.N. and Idris (1988). K Nutrient Composition of Malasian fruit, Asian Food Habits Project. J. Fruits and Veg. 10: $1180-1182$.

Yusof, S. and Ibrahim, N. (1994) Quality of sour sop juice pectinase enzyme treatment. Food Chem. 51: $81-83$.

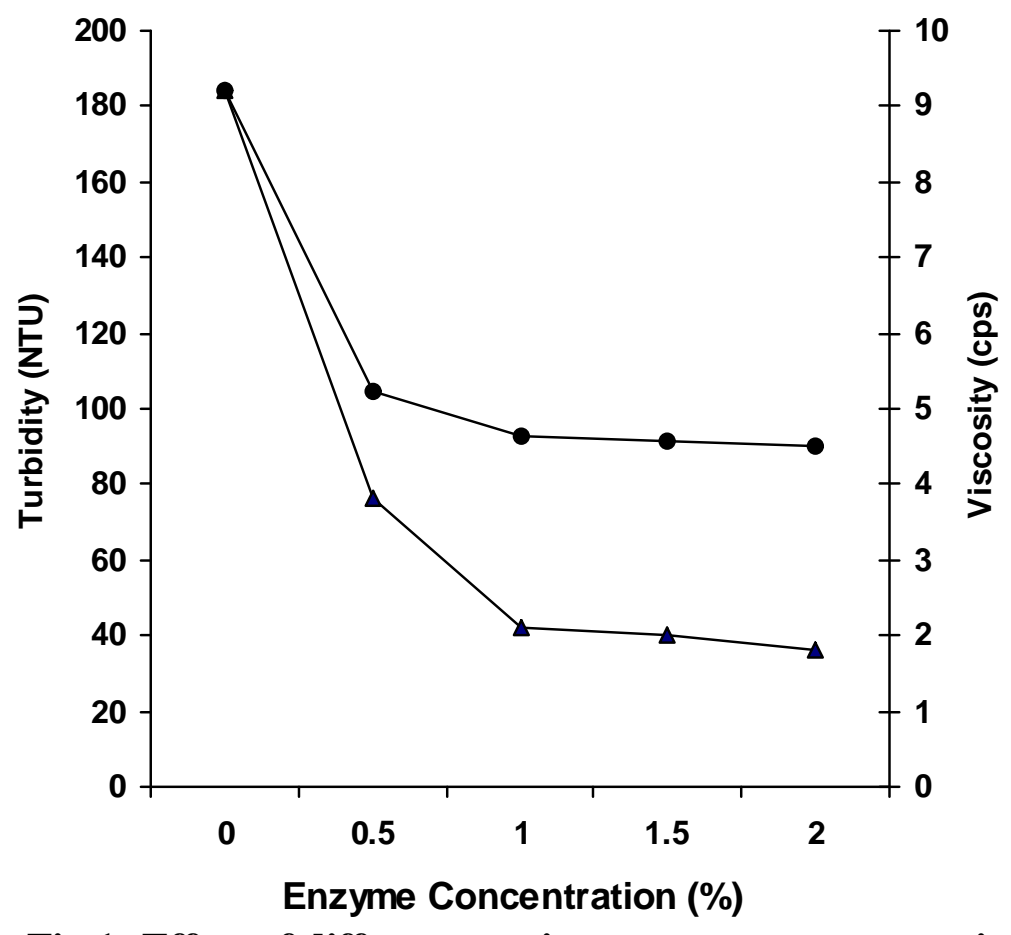

Fig 1: Effect of different pectinase enzyme concentrations on turbidity and viscosity of orange juice

$$
\neg \text { turbidity } \longrightarrow-\text { viscosity }
$$




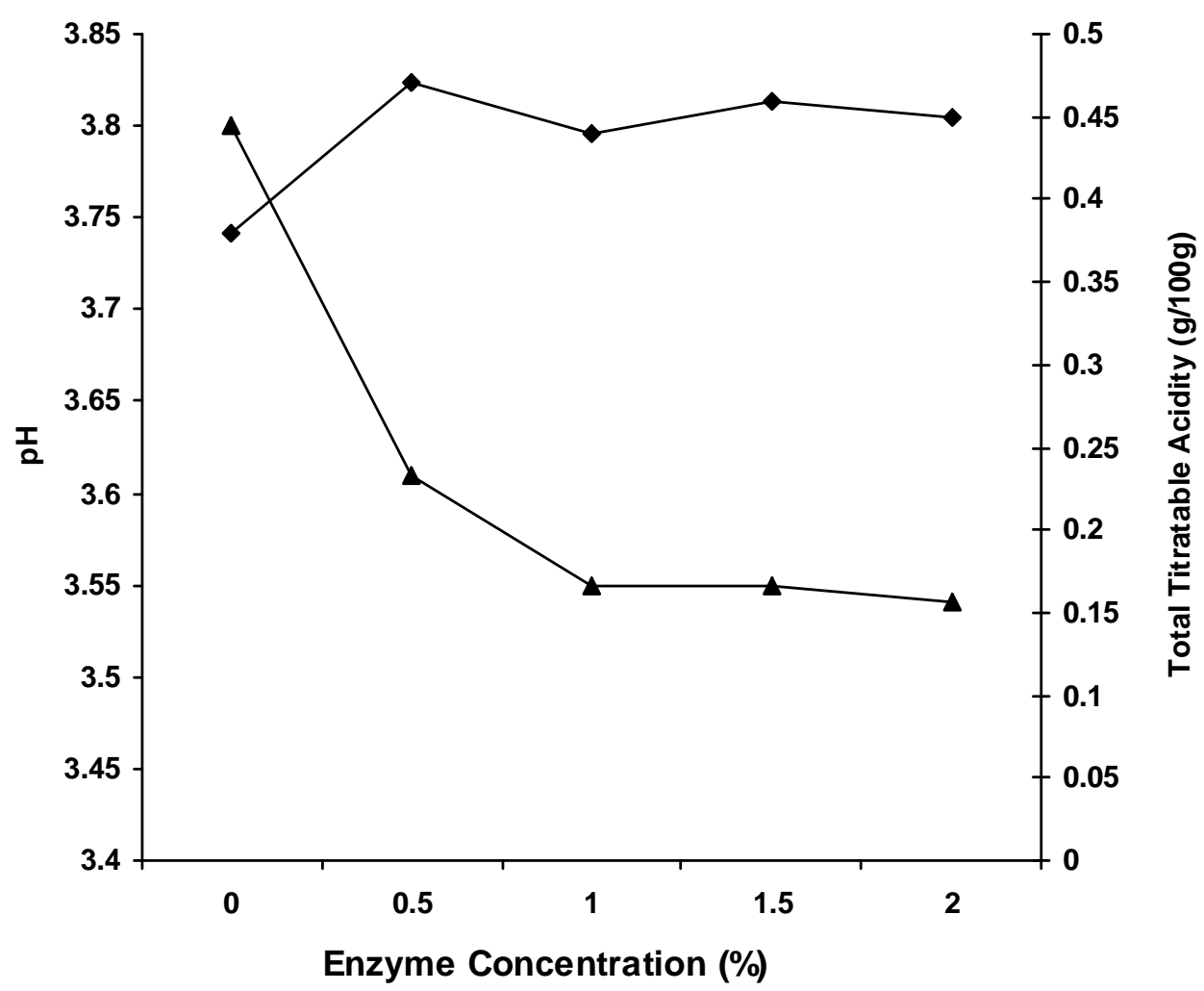

Fig 2 : Effect of different pectinase enzyme concentrations on pH and total titrtable acidity of orange juice

$\rightarrow-\mathrm{pH} \rightarrow \bullet-$ Total titratable acidity 
Table 1: Pectinase production and activity of Rhizopus oryzae strains

Strains

$\mathrm{Rx}-01$

$\mathrm{Rx}-02$

$\mathrm{Rx}-03$

Rx-04

\section{Width of clear zones on Pectinase activity (U/ml)} pectin agar $(\mathbf{m m})$

Table 2: Effect of different Pectinase concentrations on yield, total soluble solids, viscosity and turbidity of orange juice

\begin{tabular}{lllll}
\hline Enzyme & Yield (\%) & Total Soluble Solids $^{\text {ns }}$ & Viscosity $^{\text {ns }}$ (cps) & Turbidity (NTU)
\end{tabular}

\section{Concentration (\%)}

\begin{tabular}{ll}
0.0 & $73^{\mathrm{a}} \pm 0.5$ \\
0.5 & $86^{\mathrm{b}} \pm 0.4$ \\
1.0 & $97^{\mathrm{e}} \pm 0.5$ \\
1.5 & $92^{\mathrm{d}} \pm 0.2$ \\
\hline 2.0 & $89^{\mathrm{c}} \pm 0.8$ \\
& \\
\pm & Standard Deviation, $n=3$. \\
ns & Not Significantly Different $(p>0.05)$
\end{tabular}

\section{('Brix)}

$8 \quad 1,360$

$4 \quad 625$

$6 \quad 1,200$

Mean values having different superscript within column are significantly different $(p<0.05), n=3$ 
Table 3: Effect of different pectinase Concentrations on $\mathrm{pH}$, ascorbic acid and total titratable acidity of orange juice

\begin{tabular}{lccc}
\hline Enzyme Concentration (\%) & $\mathbf{p H}^{\mathrm{ns}}$ & $\begin{array}{l}\text { Ascorbic Acid }^{\mathrm{ns}} \\
(\mathbf{m g} / \mathbf{1 0 0 g})\end{array}$ & $\begin{array}{l}\text { Total Titratable } \\
\text { Acidity (TTA) }\end{array}$ \\
\hline 0.0 & $3.80 \pm 0.1$ & $48.01 \pm 1.0$ & $0.38^{\mathrm{a}} \pm 0.02$ \\
0.5 & $3.61 \pm .01$ & $48.30 \pm 0.3$ & $0.47^{\mathrm{b}} \pm 0.01$ \\
1.0 & $3.55 \pm 1.0$ & $48.31 \pm 1.0$ & $0.44^{\mathrm{b}} \pm 0.04$ \\
1.5 & $3.55 \pm 0.5$ & $48.33 \pm 0.4$ & $0.46^{\mathrm{b}} \pm 0.03$ \\
2.0 & $3.54 \pm 1.0$ & $48.59 \pm 1.0$ & $0.45^{\mathrm{b}} \pm 0.03$ \\
\hline
\end{tabular}

\pm Standard Deviation, $\mathrm{n}=3$

ns Not Significantly Different $(p>0.05)$.

Mean values having different superscript within column are significantly different $(p<0.05), \mathrm{n}=3$ 